\title{
ANALISIS KANDUNGAN LOGAM Cd, Cu, Cr DAN Pb DALAM AIR LAUT DI SEKITAR PERAIRAN BUNGUS TELUK KABUNG KOTA PADANG
}

\section{ANALYSES OF Cd, Cu, Cr AND Pb CONCENTRATION IN SEA WATER AROUND BUNGUS TELUK KABUNG, PADANG CITY}

\author{
Bustanul Arifin ${ }^{1)}$, Deswati' ${ }^{2}$, Umiati Loekman ${ }^{2)}$ \\ ${ }^{1)}$ Laboratorium Jasa Analisis Jurusan Kimia FMIPA Universitas Andalas \\ ${ }^{2)}$ Laboratorium Kimia Analitik Jurusan Kimia FMIPA Universitas Andalas \\ E-mail : ba_arifin@yahoo.co.id
}

\begin{abstract}
ABSTRAK
Penelitian mengenai analisis kandungan logam $\mathrm{Cd}, \mathrm{Cu}, \mathrm{Cr}$ dan $\mathrm{Pb}$ dalam air laut telah dilakukan di sekitar perairan Bungus, Teluk Kabung, Kota Padang dengan menggunakan metode ekstraksi pelarut. Hasil penelitian ini bertujuan untuk mengetahui kandungan logam, $\mathrm{Cu}, \mathrm{Cr}$ dan $\mathrm{Pb}$ dan sebarannya di perairan Bungus. Sampel sebanyak $200 \mathrm{~mL}$ diekstraksi dengan larutan pengompleks ammonium pyrolidin ditiokarbamat (APDC) jenuh sebanyak $2 \mathrm{~mL}$ dalam $7 \mathrm{~mL}$ metil isobutyl keton (MIBK) dan diekstrak kembali dengan $5 \mathrm{~mL}$ larutan $\mathrm{HNO}_{3} 4 \mathrm{M}$, larutan diukur absorbannya dengan Spektrofotometer Serapan Atom (SSA). Pengambilan sampel air laut dilakukan sebanyak 6 lokasi yaitu di sekitar Pelabuhan Perikanan Samudera, pantai Carolin, Depot Pertamina, Teluk Pandan, UPTD BBIP (Balai Benih Ikan Pantai) Teluk Buo dan di laut lepas, dimana tiap lokasi diambil 2 titik sampel dengan jarak antar titik sekitar $100 \mathrm{~m}$ dengan dua kali pengambilan. Dari hasil penelitian didapatkan bahwa kandungan logam Cd berkisar antara 0,006 - 0,01 ppm, Cu antara 0,0058-0,0720 ppm, Cr antara 0,0170 - 0,0890 ppm dan kandungan logam Pb berkisar antara 0,06 - 0,09 ppm. Menurut Keputusan Menteri Negara Lingkungan Hidup No. 51 Tahun 2004 kandungan logam Cr dan Pb telah melampaui standar baku mutu air laut yaitu 0,001 ppm sedangkan kandungan logam Cd dan Cu belum melampaui standar baku mutu air laut.
\end{abstract}

Kata Kunci : ekstraksi pelarut, APDC, MIBK dan SSA

\begin{abstract}
Research on metal concentrations of $\mathrm{Cd}, \mathrm{Cu}, \mathrm{Cr}$ and $\mathrm{Pb}$ was analyzed in sea water around Bungus, Teluk Kabung, Padang City by utilizing solvent extraction method. The research was conducted to see metal contents and their distribution in Bungus. Sample of $200 \mathrm{ml}$ was extracted with $2 \mathrm{ml}$ solution of saturated ammonium pyrolidine dithiocarbamate (APCD) in $7 \mathrm{ml}$ methyl isobutyl ketone (IBK) and being extracted again with $5 \mathrm{ml}$ HNO3 4M. Solution was measured its absorbance by using Atomic Absorbtion Spectroscopy $(A A S)$. Sea water samples was taken in six locations; around Samudera Fishery Port, Carolin Beach, gas station, Pandan Bay, UPTD BBIP Buo Bay and in the sea, 2 sampling points were set with 100 $m$ distance between each point. Results show the range of Cd concentration was 0.006-0.01 ppm, $\mathrm{Cu}$ was 0.0058-0.0720 ppm, Cr was 0.0170-0.0890 ppm and Pb was 0.06-0.09 ppm. Compared with the regulation of Environment Ministry number 51 Year 2004, concentrations of $\mathrm{Cr}$ and $\mathrm{Pb}$ exceeded the quality standard of sea water of $0.001 \mathrm{ppm}$. On the other hand, $\mathrm{Cd}$ and $\mathrm{Cu}$ concentrations were found below the sea water quality standard.
\end{abstract}

Keywords: AAS, APCD, MIBK, solvent exraction 


\section{PENDAHULUAN}

Pencemaran akibat kegiatan industri dapat menyebabkan kerugian besar, karena umumnya buangan/limbah mengandung zat beracun antara lain raksa $(\mathrm{Hg})$, kadmium $(\mathrm{Cd})$, krom $(\mathrm{Cr})$, timbal $(\mathrm{Pb})$, tembaga $(\mathrm{Cu})$, yang sering digunakan dalam proses produksi suatu industri baik sebagai bahan baku, katalisator ataupun bahan utama. Logam-logam ini akan membentuk senyawa organik dan anorganik yang berperan dalam merusak kehidupan makhluk hidup yang ada di dalam perairan (Darmono, 2001).

Logam berat masuk ke dalam tubuh organisme laut sebagian besar melalui rantai makanan fitoplankton merupakan awal dari rantai makanan yang akan dimangsa oleh zooplankton, zooplankton dimangsa oleh ikan-ikan kecil, ikan kecil dimangsa oleh ikan-ikan besar dan akhirnya ikan dikonsumsi oleh manusia. Proses ini berlangsung secara terusmenerus maka jumlah dari logam yang terkonsumsi juga semakin banyak dan termasuk terakumulasi dalam tubuh manusia (Darmono, 2001).

Logam berat jika sudah terserap ke dalam tubuh maka tidak dapat dihancurkan, bersifat toksik dan mengganggu kehidupan mikroorganisme. Pada manusia logam berat dapat menimbulkan efek kesehatan tergantung pada bagian mana logam berat tersebut terikat di dalam tubuh. Daya racun yang dimiliki akan bekerja sebagai penghalang kerja enzim, sehingga proses metabolisme tubuh terputus. Logam berat dapat juga sebagai penyebab alergi, karsinogen bagi manusia dan dalam konsentrasi yang tinggi akan menyebabkan kematian (Putra dan Putra, 2005).

Penelitian ini sangat perlu dilakukan dalam mengetahui kandungan logam berat yang terdapat dalam air laut di sekitar Bungus Teluk Kabung Padang, mengingat sebagian besar masyarakat di sekitar pantai banyak menggantungkan kehidupan dengan menangkap ikan. Pertimbangan lain daerah ini telah dibangunnya Depot Logistik Pertamina. Daerah ini juga sangat berpotensi dalam pengembangan daerah wisata karena pantainya yang indah dan kaya akan keanekaragaman hayati. Daerah ini juga dijadikan tempat jalur pelabuhan bagi para nelayan yang menggunakan perahu mesin, diduga dapat menambah kandungan polutan dari sisa minyak yang dipakai untuk mesin.

Beberapa penelitian sebelumnya telah dilakukan untuk melihat seberapa jauh tingkat pencemaran di daerah ini. Indikasi telah tercemarnya perairan Bungus Teluk Kabung dapat dilihat dari matinya beberapa kerang di perairan sekitar UPTD BBIP (Unit Pelaksana Teknis Daerah Balai Benih Ikan Pantai) Teluk Buo, Bungus, Teluk Kabung. Indikator lain yaitu tercemarnya perairan di Labuhan Cina Bungus Teluk Kabung oleh logam berat $\mathrm{Cu}, \mathrm{Cd}$ dan $\mathrm{Pb}$ (Handayani, 2004). Selain itu juga telah dilakukan penelitian terhadap logam berat, $\mathrm{Cu}, \mathrm{Cr}$ dan $\mathrm{Pb}$ pada kerangkerangan (Soesanti, 2004), sedimen (Yane, 2004) dan bakau (Sultana dan Willian, 2004).

Berdasarkan urian tersebut, maka perlu dilakukan penelitian tentang kandungan logam berat $\mathrm{Cu}, \mathrm{Cr}, \mathrm{Cd}$ dan $\mathrm{Pb}$ dalam air laut di sekitar perairan tersebut, mengingat 
sebagian besar masyarakatnya bergantung pada sektor perikanan dan lautan. Untuk menganalisis kandungan logam berat ini dalam air laut tersebut dapat dilakukan dengan cara ekstraksi menggunakan salah satu pengompleks. Pengompleks yang digunakan adalah ammonium pyrolidin ditiokarbamat (APDC) dalam pelarut metil isobutyl keton (MIBK). APDC ini selain berfungsi sebagai pengompleks juga berfungsi sebagai prekonsentrasi karena konsentrasi logam-logam pencemar yang terdapat dalam air laut tersebut sangat kecil sekali sehingga menyulitkan dalam pengukuran. Selain itu juga untuk memisahkan ion-ion logam yang dianalisis dari air laut yang mempunyai kandungan garam yang cukup tinggi sehingga mengganggu pengukuran dengan AAS. Metode ini telah dilakukan dalam menganalisis logam dalam air dengan konsentrasi yang kecil (Handayani, 2004).

Penelitian ini bertujuan untuk mengetahui kondisi perairan Bungus Teluk Kabung dan sekitarnya ditinjau dari logam berat yaitu $\mathrm{Cu}, \mathrm{Cr}, \mathrm{Cd}$ dan $\mathrm{Pb}$ sebagai dampak dari kegiatan pembangunan di wilayah pesisir pantai Bungus Teluk Kabung.

Manfaat dari penelitian ini diharapkan nantinya dapat memberikan informasi kepada masyarakat, pemerintah daerah tentang kualitas air laut dan menjadi tolok ukur terhadap efektifitas pengelolaan yang telah dilakukan.

\section{METODOLOGI}

\section{Tempat Penelitian}

Penelitian dilakukan di Laboratorium Kimia Analisis Terapan, Jurusan Kimia Fakultas Matematika dan Ilmu
Pengetahuan Alam, Universitas Andalas Padang.

\section{Pengambilan Sampel}

Metodologi pengambilan sampel dilakukan dengan secara terpilih, dengan memperhatikan kondisi serta keadaan dari daerah penelitian, arus dan kedalaman daerah penelitian. Hal ini dimaksudkan untuk melihat sampai sejauh mana konsentrasi zat pencemar menyebar. Pengambilan sampel air laut dilakukan di sekitar perairan Bungus Teluk Kabung Padang sebanyak 6 lokasi, pengambilan sampel, di setiap lokasi dilakukan 2 titik pengambilan, yaitu :

1. Di sekitar Pelabuhan Perikanan Samudra \pm 200 m dari tepi pantai

2. Di sekitar Pantai Carolin $\pm 100 \mathrm{~m}$ dari tepi pantai

3. Di sekitar Depot Pertamina $\pm 200 \mathrm{~m}$ dari tepi pantai

4. Arah Teluk Pandan $\pm 300 \mathrm{~m}$ dari tepi pantai

5. Depan UPTD BBIP $\pm 200 \mathrm{~m}$ dari tepi pantai

6. Laut lepas $\pm 500 \mathrm{~m}$ dari tepi pantai

\section{Persiapan Sampel}

Sampel diambil berdasarkan tiap titik yang telah ditetapkan, dimana tiap titik diambil sebanyak 1 Liter. Sampel yang telah diambil kemudian diawetkan dengan menggunakan asam nitrat $65 \%$. Untuk 1 Liter sampel ditambahkan sebanyak $2 \mathrm{~mL}$ asam nitrat pekat.

\section{Alat dan Bahan}

Alat

Alat yang digunakan adalah Spektrofotometer Serapan Atom (AAS), pH meter, Neraca Analitik, Pemanas, 
Analisis Kandungan Logam $\mathrm{Cd}, \mathrm{Cu}, \mathrm{Cr}$ dan $\mathrm{Pb}$ dalam Air Laut di Sekitar Perairan Bungus Teluk Kabung Kota Padang

Shaker, Erlenmeyer, Corong pisah, Buret, dan alat-alat gelas lainnya.

\section{Bahan}

Asam nitrat $65 \%, 4 \mathrm{M}$ dan 0,15 M, Metil isobutil keton (MIBK), Ammonium pyrolidin ditiokarbamat (APDC), Natrium hidroksida $(\mathrm{NaOH})$, Kalium bikromat $\left(\mathrm{K}_{2} \mathrm{Cr}_{2} \mathrm{O}_{7}\right)$ dan Tembaga $(\mathrm{Cu})$.

\section{Prosedur Kerja}

Prekonsentrasi Sampel dengan Metode Ekstraksi Pelarut

Dipipet $200 \mathrm{~mL}$ sampel air laut dimasukkan ke dalam gelas piala $250 \mathrm{~mL}$ yang berisi $2 \mathrm{~mL}$ APDC $1 \%$, atur $\mathrm{pH} 4$ dan panaskan sampai mendidih. Setelah dingin sampai suhu kamar, ditempatkan dalam Erlenmeyer dan tambahkan $7 \mathrm{~mL}$ MIBK kemudian digoyang dengan shaker selama 20 menit. Larutan tersebut di masukan ke dalam corong pisah dan biarkan selama 20 menit. Ambil lapisan organik (atas) dan tempatkan dalam erlenmeyer.

Untuk ekstraksi kembali, dipipet $5 \mathrm{~mL}$ $\mathrm{HNO}_{3} \quad 4 \mathrm{~N}$ dan dimasukkan ke dalam lapisan organik yang dipisahkan tadi, diaduk selama 20 menit. Lalu campuran dimasukkan ke dalam corong pisah sampai ditemukan bidang batas ( \pm 20 menit). Diambil lapisan bawah (lapisan asam) dan dianalisis dengan SSA (Haraguchi dan Agati, 1995) Hal yang sama juga dilakukan terhadap masing-masing larutan standar dari logam yang dianalisis. Tujuan prekonsentrasi dari sampel dengan metode ekstraksi pelarut adalah untuk memisahkan ion logam yang ditentukan dengan senyawa pengganggu khususnya dalam air laut yaitu kadar garam yang tinggi dan mempertinggi kepekaan analisis dalam pengukuran dengan Spektrofotometer Serapan Atom.

\section{Rancangan Percobaan}

Untuk mengetahui kandungan logam berat $\mathrm{Cu}$ dan $\mathrm{Cr}$ pada air laut maka akan digunakan rancangan acak kelompok (RCBD) (randomized completely block design), dengan 2 perlakuan dan 6 kelompok. Sebagai perlakuan adalah waktu pengambilan sampel dan sebagai kelompok adalah lokasi pengambilan sampel (Anderson, 1987).

\section{HASIL DAN PEMBAHASAN}

Kandungan Logam Cu dalam air Laut

Dari hasil penelitian terhadap air laut didapatkan konsentrasi logam $\mathrm{Cu}$ pada 12 titik pengambilan sampel seperti terlihat pada Gambar 1 di bawah ini:

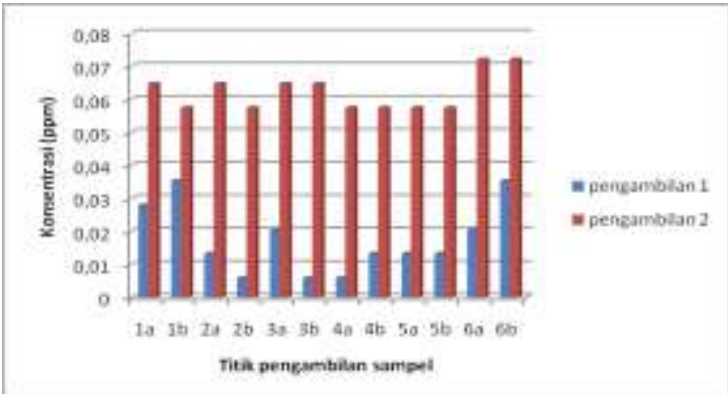

Gambar 1. Hasil pengukuran logam $\mathrm{Cu}$ pada 12 titik lokasi pengambilan sampel

Gambar 1 menunjukkan hasil pengukuran logam berat $\mathrm{Cu}$ dalam air laut di perairan sekitar Bungus Teluk Kabung berkisar antara 0,0058 - 0,0720 ppm. Kisaran ini pada pengambilan II telah melewati standar baku mutu yang ditetapkan oleh pemerintah yaitu sebesar 0,05 ppm sedangkan pada pengambilan I masih dibawah ambang batas. Konsentrasi logam $\mathrm{Cu}$ pada pengambilan I konsentrasinya masih di bawah ambang batas sedangkan pada pengambilan II telah melampaui 
ambang batas. Hal ini disebabkan karena faktor kondisi air laut yang berbeda. Pada pengambilan I kondisi air laut pasang surut dan gelombang laut cukup tenang sedangkan pada pengambilan II kondisi air laut pasang naik dan gelombang air laut besar (faktor kecepatan arus) sehingga akan menyebabkan terjadinya pengadukan sedimen dengan air laut. Konsentrasi tertinggi terdapat di lokasi 6 pada pengambilan II yaitu di laut lepas. Pada air laut di lautan lepas kontaminasi logam berat biasanya terjadi secara langsung dari atmosfir atau karena tumpahan minyak dari kapal-kapal tanker yang melaluinya dan juga dari mineral-mineral yang banyak terkandung di dalam laut itu sendiri. Pengaruh gelombang dan arus yang cukup besar, maka logam $\mathrm{Cu}$ juga ikut terbawa sehingga akan menyebabkan daerah di sekitar perairan Bungus Teluk Kabung terkontaminasi logam $\mathrm{Cu}$.

\section{Analisis Logam Cd dalam Air Laut}

Dari hasil penelitian terhadap air laut didapatkan konsentrasi logam $\mathrm{Cd}$ pada enam lokasi dengan dua belas titik pengambilan sampel seperti terlihat pada Gambar 2.

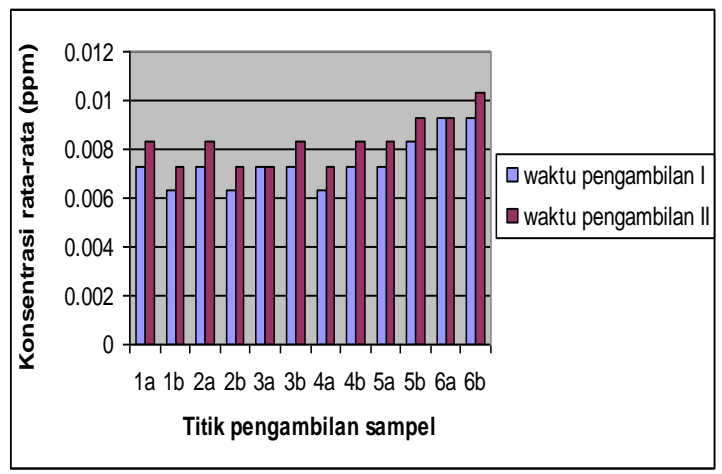

Gambar 2. Hasil pengukuran logam $\mathrm{Cd}$ pada 12 titik lokasi pengambilan sampel

Gambar 2 terlihat bahwa nilai konsentrasi logam Cd pada air laut di sekitar perairan Bungus Teluk Kabung berbeda-beda berkisar antara 0,0063- 0,0103 ppm. Kandungan $\mathrm{Cd}$ secara umum berada dibawah standar baku mutu yang ditetapkan oleh pemerintah yaitu sebesar 0,01 ppm Konsentrasi Cd tertinggi pada lokasi Laut lepas sebelah kanan (6b) yaitu 0,0103 ppm pada waktu pengambilan II kandungan logam $\mathrm{Cd}$ terendah pada lokasi di sekitar TPI, Pantai Carolin dan Teluk Pandan (1b, 2b dan 4a) yaitu 0,0063 pada waktu pengambilan I.

Konsentrasi Cd umumnya lebih tinggi pada lokasi 6 dibandingkan pada lokasi 1, 2, 3, 4 dan 5. Hal ini menunjukkan bahwa konsentrasi $\mathrm{Cd}$ yang berasal dari laut lepas lebih besar dibanding konsentrasi $\mathrm{Cd}$ yang berasal dari aktifitas di sekitar perairan tersebut. Konsentrasi $\mathrm{Cd}$ pada waktu pengambilan I dan pengambilan II terdapat perbedaan nyata. Hal ini disebabkan karena pada waktu pengambilan II kondisi perairan sedang mengalami pasang naik.

\section{Kandungan Logam Cr dalam Air Laut}

Dari hasil penelitian terhadap air laut di sekitar perairan Bungus Teluk Kabung Padang, didapatkan konsentrasi logam $\mathrm{Cr}$ pada dua belas titik pengambilan sampel dapat dilihat pada Gambar 3

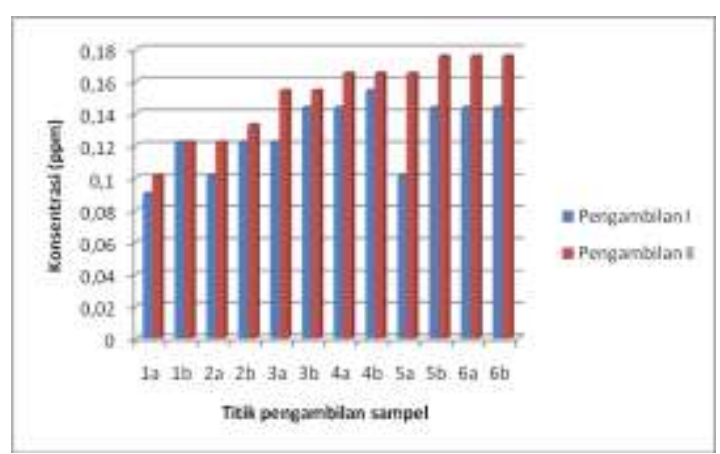

Gambar 3. Hasil pengukuran logam $\mathrm{Cr}$ pada 12 titik lokasi pengambilan sampel

Gambar 3 menunjukkan hasil pengukuran logam berat $\mathrm{Cr}$ dalam air laut di sekitar 
Analisis Kandungan Logam $\mathrm{Cd}, \mathrm{Cu}, \mathrm{Cr}$ dan $\mathrm{Pb}$ dalam Air Laut di Sekitar Perairan Bungus Teluk Kabung Kota Padang

perairan Bungus Teluk Kabung berkisar antara 0,089 - 0,17 ppm. Kisaran ini telah melampaui nilai ambang batas yang telah ditetapkan pemerintah yaitu 0,001 ppm. Konsentrasi $\mathrm{Cr}$ pada pengambilan II lebih tinggi, hal ini disebabkan karena pada pengambilan II ini kondisi air laut sedang pasang naik dan gelombang juga besar. Konsentrasi $\mathrm{Cr}$ tertinggi ditemukan pada lokasi 6 (menuju laut lepas) pada pengambilan II yaitu $0,17 \mathrm{ppm}$. Ternyata konsentrasi logam $\mathrm{Cr}$ memang sudah cukup tinggi di lautan lepas, sehingga karena faktor gelombang yang cukup besar logam $\mathrm{Cr}$ akan ikut terbawa dan akan menyebabkan daerah di sekitar perairan Bungus, Teluk Kabung akan terkontaminasi. Dalam badan perairan $\mathrm{Cr}$ masuk secara alamiah oleh beberapa faktor fisika seperti erosi yang terjadi pada batuan mineral, kebakaran hutan dan debu-debu serta partikel-partikel Cr yang ada di udara akan dibawa turun oleh air hujan. Secara kimiawi dapat berupa pelapukan batubatuan dan aktifitas gunung berapi.

Konsentrasi logam $\mathrm{Cr}$ stabil pada beberapa titik pengambilan sampel, hal ini disebabkan karena $\mathrm{Cr}$ memang sudah cukup banyak terakumulasi di perairan sekitar Bungus Teluk Kabung Padang. Beberapa faktor lain yang menyebabkan konsentrasi $\mathrm{Cr}$ cukup tinggi adalah karena aktifitas di sekitar perairan tersebut. Kondisi ini dapat dilihat pada lokasi 1 dan 2 dimana pada lokasi ini terdapatnya kapal-kapal yang berlabuh yang membuang air balasnya kelaut dan juga karena lokasinya tidak begitu jauh dari bibir pantai sehingga sering terjadi pengadukan air dengan sedimen yang banyak mengandung logam $\mathrm{Cr}$.

\section{Kandungan Logam Pb dalam Air Laut}

Dari hasil penelitian terhadap air laut didapatkan konsentrasi logam $\mathrm{Pb}$ pada enam lokasi dengan dua belas titik pengambilan sampel seperti terlihat pada Gambar 4

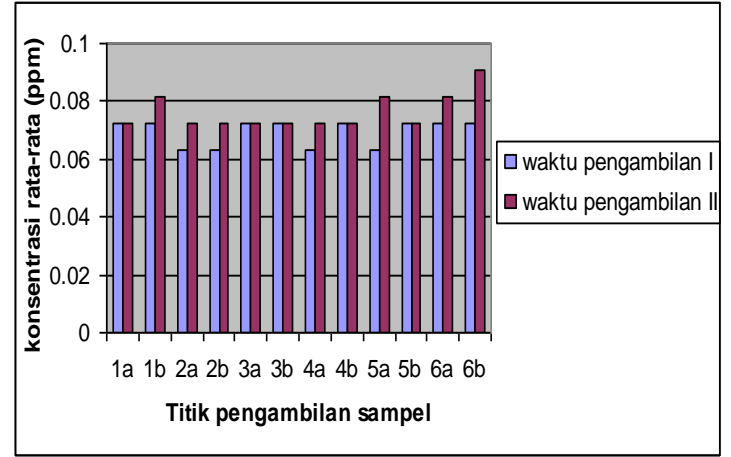

Gambar 4. Hasil pengukuran logam $\mathrm{Pb}$ pada 12 titik lokasi pengambilan sampel

Gambar 4 terlihat bahwa nilai konsentrasi logam $\mathrm{Pb}$ relatif hampir sama di setiap daerah titik sampel. Kandungan logam $\mathrm{Pb}$ dalam air laut di sekitar perairan Bungus Teluk Kabung berkisar antara 0,0630 0,0907 ppm. Kandungan logam $\mathrm{Pb}$ telah melewati standar baku mutu yang ditetapkan oleh pemerintah yaitu sebesar $0,05 \mathrm{ppm}$ Konsentrasi $\mathrm{Pb}$ tertinggi pada lokasi Laut Lepas sebelah kanan (6b) yaitu 0,0907 ppm pada waktu pengambilan II dan kandungan logam $\mathrm{Pb}$ terendah pada lokasi Pantai Carolin, Teluk Pandan dan didepan BBIP (2a, 2b 4a dan 5a) yaitu 0,0630 ppm pada waktu pengambilan I.

Konsentrasi logam $\mathrm{Pb}$ lebih tinggi pada lokasi 6 dibandingkan pada lokasi 1, 2, 3, 4 dan 5. Hal ini menunjukkan bahwa konsentrasi logam $\mathrm{Pb}$ yang berasal dari laut lepas lebih besar dibandingkan dari lokasi lain. Ada kemungkinan pencemaran ini disebabkan oleh tumpahan bahan bakar dari kapal-kapal yang melewati laut lepas tersebut dan juga berasal dari batuan- 
batuan yang ada dalam dasar laut. Konsentrasi $\mathrm{Pb}$ pada waktu pengambilan I dan pengambilan II terdapat perbedaan nyata. Hal ini disebabkan karena pada waktu pengambilan II kondisi perairan sedang mengalami pasang naik.

\section{SIMPULAN}

Dari hasil penelitian analisis kandungan logam $\mathrm{Cu}, \mathrm{Cd}, \mathrm{Cr}$ dan $\mathrm{Pb}$ pada air laut di sekitar perairan Bungus Teluk Kabung Padang, dapat disimpulkan sebagai berikut:

Kandungan logam $\mathrm{Cu}, \mathrm{Cd}, \mathrm{Cr}$ dan $\mathrm{Pb}$ dalam air laut di sekitar perairan Bungus Teluk Kabung berturut-turut adalah: 0,0058 - 0,0720 ppm, 0,0063 - 0,0103 ppm, 0,089 - 0,170 ppm dan 0,0630 0,0907 ppm.

Menurut Keputusan Menteri Negara Lingkungan Hidup No. 51 Tahun 2004 kandungan logam $\mathrm{Cr}$ dan $\mathrm{Pb}$ telah melampaui standar baku mutu air laut yaitu 0,001 mg/L, sedangkan logam Cd belum melewati standar baku mutu air laut yang ditetapkan.

Untuk logam $\mathrm{Cu}$ pada pengambilan I belum melampaui standar baku mutu air laut yaitu 0,05 ppm, tetapi untuk pengambilan II konsentrasi logam $\mathrm{Cu}$ telah melampaui standar baku mutu yang ditetapkan.

\section{DAFTAR PUSTAKA}

Anderson, R.L. 1987. Practical Statistics For Analytical Chemist. Van Nostrand Reinhold Company Inc. New York.

Darmono. 2001. Lingkungan Hidup dan Pencemaran Hubungannya Dengan Toksikologi Senyawa Logam. UI-Press. Jakarta

Handayani, A. 2004. Analisa Beberapa Kandungan Logam Berat $\mathrm{Cd}, \mathrm{Pb}$, dan $\mathrm{Cu}$ Dalam Air Laut Disekitar Manggrove Labuhan Cina Bungus Teluk Kabung Padang. Skripsi, Jurusan Kimia. Fakultas Matematika dan ilmu Pengetahuan Alam. Universitas Andalas. Padang

Haraguchi, H., T Agaki. 1995. Application Of Atomic Absorption Spectrometry to marine Analysis dalam S, J, Hasweel. Analytical Spectroscopy Library, Theory, Design and Application. Vol 5. Elsevier Amsterdam. Nederland. 1995.

Menteri Negara Kependudukan dan Lingkungan Hidup. Keputusan Menteri Negara Kependudukan dan Lingkungan Hidup Nomor 51/MENKLH/2004 Tentang Baku Mutu Air Laut untu Perairan Pelabuhan. Jakarta

Putra S.E dan Putra J.A. 2005. Bioremoval Metode Alternatif Untuk Menanggulangi Pencemaran Logam Berat. www.Che-is-try.org

Suzyanna. 2001. Model Ekologi Pengolahan Kawasan Pesisir dan Daerah Aliran Sungai Secara Terpadu. Makalah Falsafah Sains. Program Pasca Sarjana-S3. IPB. Bogor 